\title{
The Influence of Project-Based Learning Model on Creativity and Cognitive Learning Outcomes of the Students of SMAN 1 Amarasi Timur, Indonesia
}

\author{
Rosalinda Stheylani Sakbana ${ }^{1}$, Widha Sunarno ${ }^{2}$, Sri Budiawanti ${ }^{3}$ \\ ${ }^{1,2,3}$ Faculty of Teacher Training and Education, Universitas Sebelas Maret, Indonesia \\ Email: stheylani@student.uns.ac.id
}

\begin{abstract}
Creativity is one of four crucial competencies for students in the 21 st century. It has an important role in forming a superior generation to face challenges 4.0. This research is set to determine the difference of the influence of using the project-based-learning model on the students' creativity and cognitive learning outcomes. It is experimental research by using non-parametric data analysis techniques. Kruskal Wallis test is employed to test hypothesis then a post hoc follow-up test (Mann-Whitney $U$ ) is carried out. The sample is the entire population of the students of class X SMAN 1 Amarasi Timur, Indonesia. Creativity and cognitive learning outcomes are measured by using material momentum and impulse. Student's creativity is measured by using a closed questionnaire that consists of positive, negative statements, and project work results. Meanwhile students' cognitive learning outcomes are measured using a multiple-choice test with 22 questions. The results research inform that there is a significant influence of using the project-basedlearning model on students' creativity and cognitive learning outcomes.
\end{abstract}

Keywords: Project-Based Learning, Creativity, Cognitive Learning Outcomes.

\section{A. INTRODUCTION}

Education is a basic need that must be possessed by all humans because they can develop their abilities comprehensively through it. School education is carried out by providing references, forming a will, and developing students' creativity in teaching and learning activities (Martaida, T., 2017)

Professional educators are needed in the implementation of teaching and learning activities to achieve good education as expected by the societies Martaida, T., 2017, but Tabun et al., 2019 said that with the implementation of teaching and learning activities in the classroom, many teachers close the opportunities for the students' criticism by not providing learning that increases their creativity. As a competent teaching staff, the role of teachers is very important because they have the main function of forging, providing teaching, training, guiding, and evaluating students through formal primary and secondary education (Law No. 14 of 2005).

Mulyasa, (2011) states that teacher quality is viewed from two aspects, namely the process and the results "when students are more active in the learning and social process, physically and mentally, they will get involved in terms of process. It shows that quality of teachers is achieved, and in terms of results, namely: during classroom learning activities, most of the students' abilities can improve so that 
better basic competency is achieved. Through these descriptions, improvements and breakthroughs are needed so that learning objectives can be achieved.

Especially in physics, one of the problems encountered in the world of education is the lack of students' involvement in learning activities. The students do not get encouragement in finding the knowledge itself, but they just memorize what the teachers say. It indicates the incompetence of students to find solutions for the problems, especially when the problems involve the concept of physics.

Based on observations in class X-MIA of Senior High School (SMAN) 1 Amarasi Timur shows that the students' are less involved in the learning activities and passive in the classroom because it is dominated by the role of the teacher. Based on the above explanation, physics learning material is expected to provide real experiences so that scientifically the students can accept and understand the concepts of physics. Besides, the students can meet the expected learning outcomes.

Applying a learning model that fits the target is one way of implying that make students can be directly involved in understanding the concept of physics. Four learning models are in line with the scientific approach, namely: inquiry, discovery-learning, project-based-learning, and problem-based learning. These learning models are oriented towards the active role of students, one of which can be used is a project-based learning model.

Project-based-learning is a learning model that focuses on learning activities through contextually complex activities (Indrawan et al., 2020) meaning that in this learning students conclude understanding based on direct experience. Project-based learning is redefined based on constructivist learning which emphasizes students to collect their knowledge, this is in line with Indrawan's opinion. This project-based learning focuses on concept and problem solving, it allows the students to work independently in reconstructing learning that ends in presenting the results. It is concluded that project-based learning is used in teaching and learning activities where students are involved to integrate their understanding in design, problemsolving, and lead to product presentation.

According to observations carried out at Senior High School (SMAN) 1 Amarasi Timur, it turns out that ideas and updates are needed to make the props that can be used in learning activities because it is found that the props in the physics laboratory are still limited by using equipment that can be found around the environment. This is strengthen by the opinion of (Liliana, 2009) which states that the students' creativity can be formed when the students experiment with selfcreated tools and simple materials that can be found around the house and them.

This high-quality generation is supported by skills that include collaboration, innovation, digital literacy, initiative, accountability, productivity, responsibility for practical intelligence, creativity, communication, business and management, leadership, high ethical standards, professionalism, dynamics, agility, resilience, flexibility, critical thinking, and problem-solving (National Academy of Engineering, 2004); (Trilling \& Fadel, 2009) Creativity is a competency that must be possessed by students in the 21st century, the National Education Association (n.d.) identifies the 
skill as "The 4Cs." "The 4Cs" covers critical thinking, creativity, communication, and collaboration.

Creativity is a skill in getting something new, have an authentic character, including its expertise in creating new diverse, and unique ideas in perfecting new solutions (Leen et al., 2014). That means the creativity has a significant role in building a sustainable future. (Semiawan, 2009), defines creativity as the ability to change and update things that are previously owned to form a new concept. Torrance describes creativity into four components, namely: fluency, flexibility, elaboration, original.

\section{B. LITERATURE REVIEW}

\section{Project-Based Learning Model}

Thomas (Hosnan, 2014) states that project-based learning is an assessment that requires interlocking work, based on questions or problems that ask the students to be involved in designing, finding solutions, investigating, drawing conclusions, and giving the freedom to work independently so as ends in the appointment of results.

\section{Creativity}

Creativity can also explain a skill that generates unique or unusual and unexpected ideas (Alrubaie dan Esther., 2014). (Torrance, \& Presbury., 1984) stated that the main characteristics of creativity are Fluency, Flexibility, Elaboration, and Originality. (1) Fluency, the ability to create new ideas, (2) Flexibility is the ability to make various ideas, (3) Elaboration is the ability to describe, add to, and evacuate ideas, (4) Original is the ability to create extraordinary ideas.

\section{Students' Cognitive Learning Outcomes}

Cognitive includes understanding, then understanding is the earnestness regarding a matter acquired through the thought process (also initiative, response, etc.), so to speak is a way to learn something through real experience. According to Bloom, knowledge is a domain that consider the development of intellectual abilities and skills. Winkel, 2019 said that the place to regulate knowledge activities is through the mental activity itself. Winkel, (2019) also said that the special characteristics of cognitive learning are based on the acquisition of the use of forms that reflect objects or events. Those objects are displayed or displayed personally by an intellectual reaction.

\section{METHOD}

The research employs an experimental method with non-parametric analysis techniques. This non-parametric analysis technique can be used when the qualifications of parametric statistics do not meet the standards. Whereas, the sample in this research is the whole population. The statistical analysis is the Kruskal 
Wallis test with the test criteria: the significance level of $P_{\text {-value }} \geq 0.05$ accepting the null hypothesis and if $\mathrm{P}_{\text {-value }} \leq 0.05$ then the result is rejecting the null hypothesis.

This test contains twenty-five questions arranged in a closed questionnaire which includes three indicators, namely: fluency, flexibility, and elaboration. The three indicators are linked to each other in a positive and a negative statement, then the practical test uses the scores from the results of the projects that the students work on. The student's ability to complete a multiple-choice test of 25 items is a cognitive learning outcome measured in this research.

\section{RESULTS AND DISCUSSION}

Data on tests of creativity and students' learning outcomes are measured and checked using predetermined guidelines. The results of the descriptive analysis of scores for each aspect of creativity are presented in Table 1 and Table 2 below:

Table 1. Creativity Data Description

\begin{tabular}{|lccccc|}
\hline Creativity Attitude Aspects & Min & Max & Mean & Std.Dev & Median \\
\hline Low & 62 & 87 & 75 & 6.73 & 76 \\
High & 67 & 90 & 79 & 5.36 & 80 \\
\hline Creativity Skills Aspects & & & & & \\
\hline Low & 78 & 89 & 79 & 4.08 & 78 \\
High & 73 & 90 & 83 & 3.38 & 84 \\
\hline
\end{tabular}

Through Table 1, it is clear that the data description from the students with low creativity gets an average score for the learning outcomes of creativity in the aspects of attitudes and skills, respectively 75 and 79 . While the students who have high creativity in the realm of attitudes and skills get a score of 79 and 83 . The results of learning knowledge in this study are how the knowledge possessed by students is poured out through test work, momentum material, and impulses. After that, they are then analysed. The following shows the data on students' learning outcomes in Table 2.

Table 2. Achievement Value Data Description of Cognitive Aspect

\begin{tabular}{|lcccccc|}
\hline Learning Model & $\mathrm{N}$ & Min & Max & Mean & Std.Dev & Median \\
\hline Low & 31 & 62 & 87 & 75 & 6.73 & 76 \\
\hline
\end{tabular}

The next step is to analyze whether there are differences in the influence of using the project-based learning model on students' creativity and cognitive or not. This analysis uses the SPSS 18 program with the test is the non-parametric statistical analysis test of Kruskal Wallis test. The Kruskal Wallis test can be used when the qualifications on the use of parametric statistics do not meet the standards. The results of the Kruskal Wallis test are presented in Table 3 and Table 4 below: 
Table 3. Kruskal Wallis Test Creativity

\begin{tabular}{|l|r|r|}
\hline \multicolumn{1}{|c|}{ Class } & N & Mean Rank \\
\hline PjBL & 31 & 36.85 \\
Total & 31 & \\
\hline
\end{tabular}

\begin{tabular}{|l|r|}
\hline \multicolumn{2}{|c|}{ Statistics Test $\mathbf{t}^{\mathrm{a}, \mathrm{b}}$} \\
\hline Chi-square & Creativity \\
df & 5.483 \\
Asymp. Sig. & 1 \\
\hline
\end{tabular}

a. Kruskal Wallis Test

b. Grouping Variable: Class

Table 4. Learning Model with Creativity on Learning Outcomes

\begin{tabular}{|l|l|r|r|}
\hline \multicolumn{2}{|c|}{ Class } & $\mathrm{N}$ & $\begin{array}{c}\text { Mean } \\
\text { Rank }\end{array}$ \\
\hline Learning & PjBL & 31 & 52.97 \\
Outcomes & Creativity & 31 & 68.02 \\
& Total & 124 & \\
& & & \\
\hline
\end{tabular}

\begin{tabular}{|l|r|}
\multicolumn{2}{|c|}{ Statistics Test T.b $^{2}$} \\
\hline \multicolumn{2}{|c|}{ Learning Outcomes } \\
\hline Chi_Square & 3.726 \\
df & 2 \\
Asymp. Sig. & .055 \\
\hline
\end{tabular}

a. Kruskal Wallis Test

b. grouping Variable: Class

Table 3 and table 4, show the significant value of students' creativity sourced from the Kruskal Wallis test of 0.019, and the significance value of using learning models and creativity on students' cognitive learning outcomes is 0.055 . The significance of the two variables obtained is $\mathrm{P}$ value $<0.05$, then the conclusion is that the research hypothesis is accepted, this indicates that there is a significant difference in the influence of the project-based learning model and creativity on students' cognitive learning outcomes. After carry out the Kruskal Wallis test, the next post hoc test is the Mann-Whitney $U$ test, this is conducted to strengthen the decision on the Kruskal Wallis test. The Mann-Whitney $U$ test calculations are presented in Table 5.

Table 5. Post Hoc follow-up test (Mann_whitney test)

\begin{tabular}{|c|c|c|c|c|c|}
\hline \multicolumn{3}{|c|}{ Creativity } & $\mathrm{N}$ & Mean Rank & Sum of Ranks \\
\hline $\begin{array}{l}\text { Creativity } \\
\text { towards } \\
\text { Learning } \\
\text { Outcomes }\end{array}$ & dimension1 & $\begin{array}{l}\text { Upper } \\
\text { Lower } \\
\text { Total }\end{array}$ & $\begin{array}{l}31 \\
31 \\
62\end{array}$ & $\begin{array}{l}36.85 \\
26.15\end{array}$ & $\begin{array}{r}1142.50 \\
810.50\end{array}$ \\
\hline
\end{tabular}

Statistics Test 


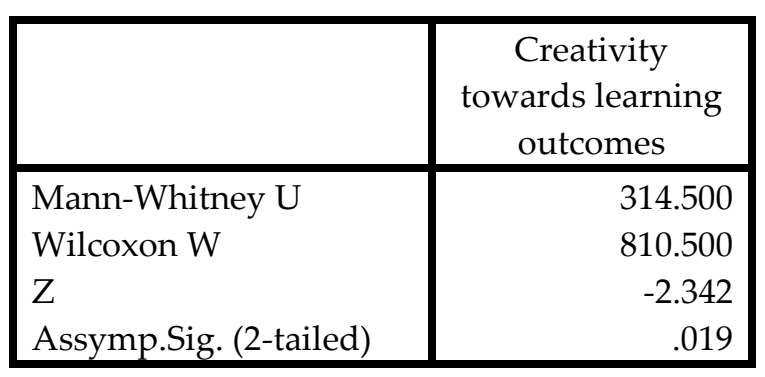

The average value obtained for high creativity is 81 and for low creativity is 71. Based on the results of the Kruskal Wallis test, it has a significant value of 0.019 ( $\mathrm{P}_{\text {-value }}$ significance level, $<5 \% \alpha=0.05$ ) then rejecting $\mathrm{H}_{0}$ and accepting $\mathrm{H}_{\text {alternative. The }}$ conclusion drawn from calculations is that there is a significant difference between project-based-learning models and creativity toward aspects of students' knowledge. Student creativity is defined as the skills of students in remodelling or updating something into something new.

This research also shows that there is an influence of high and low creativity on students' learning outcomes; it reveals is that the creativity of students can support learning outcomes. Mathisen \& Monnick (2009) say that students with high creativity can solve problems well. Creativity can help students form the needed skills and knowledge. It can be seen during research, with high creativity, the students have the desire to do experiments and do new things while they are with low creativity tend to be passive. This is an impact on the mastery of material for students who have low creativity, in contrast to those who have high creativity, they can generate new ideas through memory or the concepts so that they can create something new and following the concepts of physics.

Supported by other supporting data, namely students' project results and creativity questionnaire data, the results of this research are in line with the research of Laura at all (2011), which conclude that the differences in high and low creativity can affect the learning process and students' learning outcomes. Besides, another research from (Eragamreddy, 2013) also concludes that there are differences in high and low creativity. The obtained results are also in line with previous research by (Aktamis \& Ergin., 2008), concluding that there is an interaction between learning models and students' creativity.

\section{E. CONCLUSION}

The results of this research indicate that there is a significant difference in influence between project-based-learning models and students' creativity on students' cognitive learning outcomes. And thus, it can be said that the learning model influences the student's learning results. Therefore, this research needs to be informed to teachers that students need to be allowed to develop their creativity. The teachers also need to pay attention to and review appropriate learning models that will be applied in the learning process. It is expected that through this information, 
teachers can accommodate students creativity because this is very important in this 21st century.

\section{ACKNOWLEDGMENT}

The author would like to thank Prof. Dr. Widha Sunarno, M.Pd., and Dr. Sri Budiawanti, S.Si., M.Si., for their assistance in the compilation of this article.

\section{REFERENCES}

1. Aktamis, H. \& Ergin, O. (2008). The Effect of Scientific Process Skills Education on Student's Scientific Creativity, Science Attitudes and Academic Achievements. Jurnal Science Learning and Teaching Volume 9, 1-21.

2. Alrubaie, F., \& Daniel, E. G. S. (2014). Revisiting the Cognitive Processes of the Brainstorming Technique: Theoretical Considerations from a Synthesis of Piaget, Vygotsky and SIAM for Learning Science. Int. J. Thesis Proj. Diss, 2(3), 44-57.

3. Eragamreddy, N. (2013). Teaching creative thinking skills. International Journal of English Language \& Translation Studies. 1(2), 124-145.

4. Garaigordobil, M., \& Laura, B., (2011). Effects of a play program on creative thinking of preschool children. The Spanish Journal of Psycologi. 14(2), 608-618.

5. Hosnan, M. (2014). Pendekatan Saintifik dan Kontekstual dalam Pembelajaran Abad 21. Bogor: Ghalia Indonesia.

6. Indrawan, E., Jalinus, N., \& Syahril, S. (2020). Project Based Learning in Vocational Technology Education Study of Literature. International Journal of Scientific \& Technology Research, 9(2), 2821-2825.

7. Law of the Republic of Indonesia Number 14 of 2005 concerning Teachers and Lecturers

8. Leen, C. C., Hong, K. F. F. H., \& Ying, T. W. (2014). Creative and Critical Thinking in Singapore Schools.

9. Liliana., A. W. (2009). Gambaran Kelekatan (attachment) Remaja Akhir Putri. Fakultas Psikologi. Universitas Gunadarma.

10. Martaida, T., Bukit, N., \& Ginting, E. M. (2017). The effect of discovery learning model on student's critical thinking and cognitive ability in junior high school. IOSR Journal of Research $\mathcal{E}$ Method in Education (IOSR-JRME), 7(6), 1-8.

11. Mulyasa, E. (2011). Menjadi guru profesional menciptakan pembelajaran kreatif dan menyenangkan. Bandung: Remaja Rosdakarya, 232.

12. Semiawan, C. R. (2009). Keterbakatan, Mengapa, Apa dan Bagaimana. Jakarta: Macan Jaya Cemerlang.

13. Tabun, Y. F., Sunarno, W., \& Sukarmin. (2019). Guided inquiry model based on scientific approach to science learning of the students of SMPK Stella Maris Biudukfoho. Journal of Physics: Conference Series, 1307(1). https://doi.org/10.1088/1742

14. Torrance, E. P., \& Presbury, J. (1984). The Criteria of Success Used in 242 Recent Experimental Studies of Creativity. Creative Child \& Adult Quarterly. 
15. Trilling, B., \& Fadel, C. (2009). 21st century skills: learning for life in our times. Jossey Bass: USA. Journal of Chemical Information and Modeling, 53(9), 1689-1699.

16. Winkel, W. S. (2019). Psikologi Pengajaran. Jakarta: Grasindo. 